\title{
Regions with the Highest Suicide Rates for Children and Adolescents - Some Observations
}

\section{Kairi Kolves and Diego De Leo}

Australian Institute for Suicide Research and Prevention, National Centre of Excellence in Suicide Prevention, WHO Collaborating Centre for Research and Training in Suicide Prevention, Griffith Univeristy, Australia

"Corresponding author: Diego De Leo, Australian Institute for Suicide Research and Prevention, National Centre of Excellence in Suicide Prevention, WHO Collaborating Centre for Research and Training in Suicide Prevention, Griffith Univeristy, Australia, Tel: 617 -3735 3366 ; Fax: $61-7$ 3735 3450; E-mail: D.DeLeo@griffith.edu.au

Received date: Mar 17, 2014, Accepted date: Mar 18, 2014, Published date: Mar 25, 2014

Copyright: $\odot 2014$ Kolves $\mathrm{K}$, et al. This is an open-access article distributed under the terms of the Creative Commons Attribution License, which permits unrestricted use, distribution, and reproduction in any medium, provided the original author and source are credited.

\section{Editorial}

Childhood is often perceived as a time of innocence and happiness; unfortunately, this is not true to all children. The concept of happy childhood devastatingly conflicts with suicide in children. Indeed, research has shown that the majority of children are able to understand the meaning of self-inflicted death from 8 years of age on [1], and are capable to engage in suicidal behaviours. Although suicide in children represents a relatively rare event, it is still one of the leading causes of death in the age group 10-14 years [2]. Suicide prevalence increases in adolescence, a phenomenon that is not unexpected, as this constitutes the time of rapid developmental changes. Similarly to adults, suicide rates in children and adolescents greatly vary between countries. Our recent analysis of 81 countries between 2000 and 2009 based on the WHO Mortality database [3] revealed that the highest suicide rates for children and adolescent in both sexes were mainly found in the former Soviet Union and Central and South America (Table 1).

\begin{tabular}{|c|c|c|c|}
\hline \multicolumn{4}{|l|}{ Males } \\
\hline \multicolumn{2}{|l|}{$10-14$ years } & \multicolumn{2}{|l|}{$15-19$ years } \\
\hline Kazakhstan & 8.53 & Russian Federation & 33.28 \\
\hline Suriname & 6.36 & Kazakhstan & 31.06 \\
\hline Russian Federation & 5.47 & Lithuania & 30.15 \\
\hline Kyrgyzstan & 5.12 & Guyana & 28.49 \\
\hline Belarus & 3.94 & New Zealand & 22.38 \\
\hline Guyana & 3.77 & Belarus & 22.36 \\
\hline Ukraine & 3.36 & Estonia & 19.78 \\
\hline Ecuador & 3.34 & Ireland & 18.86 \\
\hline Lithuania & 3.3 & Finland & 17.15 \\
\hline Estonia & 3.05 & Iceland & 16.72 \\
\hline \multicolumn{4}{|l|}{ Females } \\
\hline \multicolumn{2}{|l|}{ 10-14 years } & \multicolumn{2}{|l|}{$15-19$ years } \\
\hline Guyana & 6.46 & Guyana & 24.95 \\
\hline Suriname & 6.11 & Suriname & 15.75 \\
\hline Ecuador & 3.14 & Kazakhstan & 12.28 \\
\hline Kazakhstan & 2.86 & El Salvador & 12.02 \\
\hline
\end{tabular}

\begin{tabular}{|l|l|l|l|}
\hline Nicaragua & 2.22 & Nicaragua & 11.02 \\
\hline El Salvador & 2.10 & Ecuador & 10.18 \\
\hline Colombia & 2.00 & New Zealand & 9.55 \\
\hline Trinidad and Tobago & 1.86 & Russian Federation & 7.87 \\
\hline Russian Federation & 1.85 & Mauritius & 7.61 \\
\hline Paraguay & 1.84 & Trinidad and Tobago & 7.45 \\
\hline
\end{tabular}

Table 1. Suicide rates for males and females aged 10-14 and 15-19 years in Top 10 countries

Indeed, there are sex differences: former Soviet Union countries seem to prevail in young males (they are listed among the top 10), while Southern American countries are overrepresented in females. More specifically, Kazakhstan and Russia have the highest rates for boys aged 10 to 14 and 15 to 19 years, while non-Latin Caribbean countries such as Guyana and Suriname have the highest rates for both age groups in young females. There are a few exceptions in the age group 15-19 years, where New Zealand is present for both genders (despite their declining rates), while Ireland, Finland and Iceland are present with their high rates for young males.

After considering these epidemiological data, one wonders what could be the possible contextual influences in those countries that might be hidden behind the high suicide rates at such an early stage of life. We do not aim to try to answer in full this question, as it would definitely need a deep analysis, inclusive of several societal factors (e.g., cultural, political, economic, etc); however, we would like to formulate a few simple observations. The USSR kept its suicide rates secret (i.e., unpublished) until the 1990s [4]. Since then, the suicide rates from the region have been the highest in the world [5]. The collapse of the system and the consequent transformations caused several political and social problems. Soviet programs for citizens and family policies were largely neglected during the transition; the new era brought economic sequelae (such as unemployment, inequalities, and privatisation) previously unknown to the people living under Soviet rules [6]. Those changes - in combination with heavy alcohol use influenced morbidity and mortality of newly independent countries, causing a general increase in mortality [7]. Considering that the new countries resulting from the fragmentation of the old Soviet Block did choose their own ways of building up the nation, they continued to struggle after being hit by the global economic crisis. These circumstances had also an impact for the youngest generations [8]. Similarly to the former Soviet Union, several countries in the Central 
and South America have experienced severe economic and political turbulence. The limited research originating from the area has pointed out that the countries with the highest suicide rates are poor and have low GDP [9]. Other influential factors often named in explaining the high suicide rates in young people are loss of cultural values and traditional beliefs in indigenous people [10,11]. In addition, considering that in majority of the countries hanging is still the most prevalent suicide method for young females and males, it is important to note that South American countries with the highest suicide rates have a very high prevalence of suicides by poisoning with pesticides and other chemicals (X66-X69), especially in young females. For example, the prevalence of pesticide poisoning in females in age group $10-14$ years was $81 \%$ and in age group $15-19$ years was $83.6 \%$ in Guyana while the corresponding percentages for Mexico were $14.2 \%$ and $20.6 \%$, and for Canada $0 \%$ and $1.5 \%$, respectively [3]. Although populous Asian countries such as India and China do not report their suicide data to the World Health Organization and are therefore not included into our analysis, they are widely known for the high prevalence of suicide cases involving the use of pesticides; this phenomenon is generally believed to contribute to the high suicide rates of young females in those countries [12,13]. Another important consideration while interpreting suicide rates in youth is that suicides are more likely to be underreported, especially in children. Possible factors related to the underestimation are social stigma and shame around suicide; coroner or legal officer's reluctance to determine a verdict of suicide in case of a child; disparities in death classification systems, and/or the misconception that children are unable to engage in suicidal behaviours due to their cognitive immaturity $[14,15]$. Pritchard and Hean [16] analysed potential underreporting of 18 countries in Central and South America, and evidenced very high rates of undetermined deaths, exceeding suicide rates, particularly in younger males. On the other hand, it has recently been noted that there have been improvements in the recording and registering of suicide mortality in some countries of South America [17]. There is a number of important aspects to consider for suicide prevention in children and adolescents. At the primary prevention level, it has been proven that restricting access to means is effective in reducing suicide incidents; for example, controlling their availability in South America might prevent many fatal cases of pesticide poisoning. Further, considering the vulnerability to economic fluctuations, governments could play an important role in preventing suicide by implementing strategies capable of minimizing the adverse effects of a country's economic recession [18]. Stuckler et al. [19] indicated that active labour market programmes might mitigate the adverse effect of unemployment on health. This has the potential to prevent the loss of life not only of working-age people, but also of children and adolescents.

\section{References}

1. Mishara BL (1998) Childhood conceptions of death and suicide: Empirical investigations and implications for suicide prevention. In D De Leo, A
Schmidtke, RFW Diekstra (eds). Suicide prevention: A holistic approach. Dordrecht, Boston, London: Kluwer Academic Publisher, 111-119.

2. Apter A, Bursztein C, Bertolote JM, et al (2009) Suicide on all continents in the young. In D Wasserman \& C Wasserman (eds), Oxford textbook of suicidology and suicide prevention. Oxford University Press, 621-628.

3. World Health Organization. WHO Mortality Database

4. Wasserman D, Värnik A (1998). Reliability of statistics on violent death and suicide in the former USSR, 1970-1990. Acta Psychiatr Scand Suppl 394: $34-41$.

5. Vänik P, Sisask M, Värnik A (2010) Massive increase in injury deaths of undetermined intent in ex-USSR Baltic and Slavic countries: hidden suicides?. Scand J Public Health, 38: 395-403.

6. Kõlves K, Milner A, Värnik P (2013) Suicide rates and socioeconomic factors in Eastern European countries after the collapse of the Soviet Union: Time trends between 1990 and 2008. Sociol Health Illn 35: 956-970.

7. Leon DA, Shkolnikov VM, McKee M (2009) Alcohol and Russian mortality: a continuing crisis. Addiction 104: 1630-1636.

8. From the European Centre on Health of Societies in Transition, London School of Hygiene \& Tropical Medicine, London, England (Dr Leon); and the Center of Demography and Human Ecology, Institute for Economic Forecasting, Russian Academy of Sciences, Moscow (Dr ShkolnikGoodman R, Slobodskaya H, Knyazev G (2005) Russian child mental health: A crosssectional study of prevalence and risk factors. Eur Child Adolesc Psychiatry 14: 28-33.

9. Quinlan-Davidson M, Sanhueza A, Espinosa I (2014) Suicide among young people in the Americas. J Adolesc Health, 54: 262-268.

10. Alterwain P, Basile H, Frankel D (2009) Suicide prevention in South America. In: Wasserman D and Wasserman C (eds) The Oxford Textbook of Suicidology and Suicide Prevention. Oxford University Press, 835-838.

11. Botega NJ, D'Oliveira CFA, Bertolote JM (2009) Suicide prevention in Brazil. In: Wasserman D and Wasserman C (eds) The Oxford Textbook of Suicidology and Suicide Prevention. Oxford: Oxford University Press, 841-842.

12. Patel V, Ramasundarahettige C, Vijayakumar L (2012) Suicide mortality in India: a nationally representative survey. Lancet, 379: 2343-2351.

13. De Leo D (2013) Pesticide availability and medically serious suicide attempts in China. Shanghai Archives of Psychiatry, 25: 116-118.

14. Crepeau-Hobson F (2010) The psychological autopsy and determination of child suicides: A survey of medical examiners. Arch Suicide Res 14: 24-34.

15. Grøholt B, Ekeberg $\varnothing$ (2003) Suicide in young people under 15 years: Problems of classification. Nord J Psychiatry 57: 411-417.

16. Pritchard C, Hean S (2008) Suicide and undetermined deaths among youths and young adults in Latin America: Comparison with the 10 major developed countries - A source of hidden suicides? Crisis 29: 145-53.

17. Ferrada-Noli M, Alvarado R, Florenzano F (2009) Suicide prevention in Chile. In: Wasserman D and Wasserman C (eds) The Oxford Textbook of Suicidology and Suicide Prevention. Oxford: Oxford University Press, 843-844.

18. Stuckler D, Basu S (2013) The body economic: Why austerity kills. London: Allen Lane.

19. Stuckler D, Basu S, Suhrcke M (2009) The public health effect of economic crises and alternative policy responses in Europe: an empirical analysis. Lancet 374: 315-323. 